\title{
HIGHER AND PROFESSIONAL EDUCATION: A CULTURALLY APPROPRIATE DIMENSION
}

\section{Knyazheva I. A.}

\section{INTRODUCTION}

The realities of today are associated with constant changes in the socio-economic life of our country and the world, the gradual integration of the national economy and education in the European and world economic and educational space, increasing demands on professionals, intensifying competition in the labour market, and therefore determine the need for quality higher and professional education.

The cornerstone of higher and professional education institutions is culturally appropriate pedagogical support for the training of highly qualified specialists, with formed "educational and professional competencies for the implementation of lifelong learning". The legal framework for its implementation consists of the Constitution of Ukraine, the Laws of Ukraine "On Education", "On Higher Education", "On Vocational (Technical) Education", the National Strategy for Education Development in Ukraine until 2021, the Strategy for Higher Education Development in Ukraine for 2021-2031, etc. In particular, the Law of Ukraine "On Education" (Article 5) states that "education is a state priority that ensures innovative, socio-economic and cultural development of society"2.

Many years of experience in higher and professional education, the results of domestic (V.I. Bondar, R.S. Gurevich, M.B. Yevtukh, S.A. Kalashnikov, V.G. Kremen, V.I. Lugovyi, N.G. Nichkalo, V.O. Ognevyuk, P.U. Saukh, S.O. Sysoeva, etc.) and foreign (S.I. Arkhangelsky, F.N. Gonobolin, I.F. Isayev, J. Carter, S.M. Kvyatkovsky, N.V. Kuzmina, L.M. Mitina, K.V. Petterson, U.V. Senko, V.O. Slastyonin, I.P. Smirnov, F. Shlosek, etc.) research proves the need to ensure cultural content, forms, methods and

1 Про професійну (професійно-технічну) освіту. Проєкт закону України від 12 жовтня 2020 р. № 4207. URL: http://search.ligazakon.ua/1_doc2.nsf/ link1/JI03403A.html.

2 Закон України «Про освіту»: Закон України від 05 вересня 2017 р. № 2145-VIII. URL: https://zakon.rada.gov.ua/laws/show/2145-19\#Text. 
technologies of vocational education, improving the quality of which largely depends on the deep awareness of teachers of vocational school place and role of educational processes and educational systems in the development of world cultural space, understanding the integrity of cultural diversity in education, ways to use the most valuable achievements of world culture in the process of training future qualified professionals in accordance with the needs of today.

\section{Culture in the parameters of scientific discourse: genesis and development}

The depth, complexity and multidimensionality of culture as a phenomenon has led to numerous attempts to define it, since the emergence of this concept in ancient times, when it was understood as tillage, care and cultivation of plants, care, change for the better. This agronomic interpretation, where "cultural" means that grown by humans, is not wild, is still preserved (for example, in the definition of "cultivation"). It is believed that for the first time in a figurative sense, this concept was used by M.T. Cicero in his "Tusculan conversations"3 in the sense of processing, education of soul, mind, later transforming into related concepts of "upbringing", "learning", "education". That is why the Latin "cultura" and the Greek "paideia" Plato, Socrates, Xenophon ${ }^{4}$ and other philosophers of antiquity used as synonyms, based on the idea that education itself separates man from the animal and distinguishes among other people what makes it better, developed, perfect, conscious, socialized.

In the philosophical views of T. Hobbes ${ }^{5}$ and other representatives of the New Age, there is a clear antinomy between the "natural" and "civilized" ("cultural") state of both the individual and humanity as a whole. They were convinced of the usefulness, the enormous potential of scientific knowledge, which should help man to adapt nature to their needs, change it for the better, rule in it, as well as optimally arrange social life. That is, the need for a term that contains the idea of specifically human, social "unnatural" as a sphere of development of "human existence", "human nature" as opposed to animal, natural,

${ }^{3}$ Цицерон М.Т. Сборник статей / отв. ред. Ф.А. Петровский. Москва : Издво АН СССР, 1958. $151 \mathrm{c.}$

4 Кулиев Г.Г., Курбанов Р.О., Драч Г.В. и др. Зарубежное философское антиковедение : Критич. Анализ / отв. ред. Д.В. Джохадзе ; АН СССР, Ин-т философии. Москва : Наука, 1990. 236 с.

${ }^{5}$ Гоббс Т. Левіафан, або Суть, будова і повноваження держави церковної та цивільної. Київ : Дух і Літера, 2000. 600 с. 
natural being, contributed to the introduction into scientific discourse of "culture".

At the same time, it should be emphasized that for a long time the term "culture" was not independent. Thus, in the Middle Ages a set of meanings of this word was widespread, according to which it was associated with the urban way of life. This term in the Renaissance was used only in phrases, in combination with something, as a function of something else, more specific. For example: culture of sciences, culture of arts, culture of language, etc.

F. Bacon spoke of "culture and fertilization of the mind"6. Thus, it can be argued that despite the lack of an independent term, the idea of culture as a phenomenon was implicitly present in philosophical works.

I. Niedermann ${ }^{7}$ proved that as an independent lexical unit the word "culture" appears at the end of the XVII century in the works of S. Puffendorf, who contrasted culture with "natural", believed that it includes everything produced by man. He assessed culture positively, as one that distinguishes, glorifies modern man, distinguishes him from the savage, who, according to the German philosopher, is completely deprived of it. Here the terms "culture" and "civilization" act as synonyms, carriers of good, reason, beauty, peace and are opposed to the "natural state", which is characterized negatively, because it embodies cruelty, fear, passion, ignorance. Here, for the first time in scientific discourse, the two-dimensionality of culture is defined: as a process of improvement of man, the environment and as a result of this improvement.

In the works of K. Helvetius, P. Holbach, J. Condorcet and others, culture as an expression of the universality of human existence, is part and product of free reason, a condition, a criterion of development and progress. Man here is a product of the social environment, and education, according to K. Helvetius ${ }^{8}$, completely shapes man. We find a similar understanding of culture in J. Adelung ${ }^{9}$, who believed that it enriches

${ }^{6}$ Бекон Ф. Зарубіжні письменники. Енциклопедичний довідник : у 2 т. / за ред. Н. Михальської та Б. Щавурського. Тернопіль : Навчальна книга - Богдан, 2005. T. 1. C. 116.

${ }^{7}$ Нидерман И. Культура, становление и изменение понятия и заменяющие его понятия от Цицерона до Гердера. Москва : Просвещение, 1992. 422 с.

${ }^{8}$ Французский материализм XVIII века. Учение об обществе. Хрестоматия. Москва : Либроком, 2011. 264 с.

9 Strohbach M. Johann Christoph Adelung. Ein Beitrag zu seinem germanistischen Schaffen mit einer Bibliographie seines Gesamtwerkes. Berlin; New York : Walter de Gruyter, 1984. 
man, includes all the best, intelligent, all the various manifestations of human activity. Thus, the consolidation of the classical understanding of the meaning of the term "culture" was formed in the Enlightenment and is synonymous with reasonable, moral, aesthetic improvement of man as a member of civil society.

At the same time, the study of culture as a phenomenon is associated with the names of J.G. Herder and I. Kant. It was they who were able to make a conceptual understanding of culture by isolating it from general social life as a phenomenon that is closely related to it, but not identical to it. Thus, the idea of historical universalism of culture, its self-worth and self-integrity is fundamentally new in the work of J.G. Herder and has a significant impact on its further study. The scientist concludes that man is the highest creation of nature. Man creates himself from nature and stood out from it precisely because of culture, which forms its specific essence. Culture is a product of man, but man also carries out "self-creation" thanks to culture, which "captures man and form..."10. The scientist emphasizes that man must learn to control himself and the outside world (forces of nature), because culture is not a natural given, man acquires it through his own activities and is responsible for it. Culture is the result of upbringing, because an individual without the help of others cannot reveal his skills on his own, but learns them from others, imitates patterns. That is why there is no history of the individual, a separate subject but the history of the human race and "the chain of culture and education will extend to the very edges of the earth".

I. Kant proved the idea of two-phase human development: from a natural being in which the essential forces (will, mind, and thinking) are laid down potentially, to a cultural one - rational and moral. This transition takes place when a person, through his activity, and not only his innate ability to improve, becomes free, able to overcome natural vices, with the help of will and reason to control his life.

Culture is defined by I. Kant as "the acquisition by an intelligent being of the ability to set any goals in general (hence, in its freedom)",11 and is specifically a social mechanism that translates human "essential forces" through education, human development of relevant activities, ancestral abilities and is a prerequisite for self-development of both the individual and all mankind.

10 Гердер И.Г. Идеи к философии истории человечества. Москва : Издательство «Наука», 1977. С. 230-231.

${ }^{11}$ Кант И. Критика чистого разума. Москва : Наука, 1999. С. 464. 
In Hegel's legacy, the term "culture" is synonymous with "education", the meaning of which is the exaltation of man to all "stages of the movement of the world spirit ${ }^{12}$ through abstract thinking". The habit of this abstraction in consumption, cognition, knowledge and behavior is culture (Bildung), he wrote, trying to overcome the contradiction between the Enlightenment and the romantic understanding of culture. That is, it is about understanding culture as a result and a means of revealing the human in man. Hegel's idea of "autonomy", "incompleteness" of the individual emphasizes its desire for selfdevelopment.

E. Taylor, using the term "culture" as a synonym for the term "civilization", defines it "as a complex whole that contains knowledge, faith, art, law, morality, customs and other abilities and habits acquired by man as a member of society"13. In the subsequent history of mankind, it became clear that civilization and culture are a contradictory unity, acting as its functional unit: if culture is a system of meaning of human existence, then civilization - the subject resource of culture. Civilization and culture are also two different means of realizing the creative forces of man. If in culture everything material is subordinated to the spiritual, then within civilization the spirit serves the material ${ }^{14}$.

The surge of research interest both in the phenomenon of culture itself and in the concept that indicates it dates back to the twentieth century, which is confirmed by numerous scientific and philosophical (P.S. Gurevich, L.G. Ionin, L.N. Kogan, G.O. Smirnov, etc.) and culturological (L.I. Bereznytska, A. Weber, V.V. Kizima, C. Klakhon, Y.V. Tikhonravov, etc.) research. A. Weber and K. Klakhon distinguish explanatory-descriptive (based on a list of everything that can be covered by the concept of culture - beliefs, knowledge, art, morality, laws, customs); historical (emphasis is placed on the processes of social inheritance, traditions); normative (focus on both the idea of lifestyle and the idea of ideals and values); psychological (in which attention is focused either on the processes of adaptation to the environment, or on the learning process, or on the formation of habits; culture matures as a special form of sublimation of mental reactions in response to social), structural (attention focuses on the structural organization of culture),

${ }^{12}$ Гегель Г.Ф.В. Философия права. Москва : Мысль, 1990. С. 83.

13 Тайлор Э.Б. Первобытная культура / пер. с англ.. Москва : Политиздат, 1989. С. 21.

14 Культурологія: теорія та історія культури : навчальний посібник / за ред. I.I. Тюрменко. Київ : Центр навчальної літератури, 2010. 370 с. 
genetic (which define culture from the standpoint of its origin: as a product or artefact, as one that is separated from what is not culture, as symbols and ideas) the concept of interpretation of culture ${ }^{15}$.

The research of D. Kaplan and R.A. Manners ${ }^{16}$ added new interpretations of the definition of culture. Here are some of them:

- adaptive definitions (culture is seen as a way of activity inherent in people, through which they adapt to natural conditions);

- anthropological (based on the fact that culture is a set of products of human activity that oppose nature);

- sociological (culture is understood as a set of ideas, principles of functioning of social institutions that ensure the collective activities of people);

- ideational (emphasize the origin of culture as a product of the history of a developing society through continuity between generations, through the transmission of human experience);

- symbolic (culture is represented as a system of symbols that are produced by mankind);

- didactic (consider culture as something that a person has learned in the process of life);

- hermeneutic (emphasize that culture is a variety of texts that the community interprets according to its level of development);

- functional (consider culture through the system of functions it performs in society);

- technological (understand culture as ways (technologies) of human activity in all its manifestations).

During the Soviet era, a somewhat one-sided understanding of culture as a set of material and spiritual values created and formed by mankind in the process of socio-historical practice and those that characterize the achieved level in the development of society was widespread ${ }^{17}$.

We support N.V. Voroshilov's position on the fruitfulness of "raising the question of the possibility and necessity of analysing the internal structures of culture in terms of their interaction, dialogue", polyphonic "mutual understanding and mutual enrichment" 18 .

15 Kroeber A.L., Kluckhon C. Culture. A Cretical Review of Concept and Definitions. Harvard Univ., 1952. P. 10-29.

${ }^{16}$ Kaplan D., Manners R.A. Culture Theory. New York, 1972.

17 Философский словар / под ред. М.М. Розенталя. Москва : Политиздат, 1975. C. 196.

18 Мотрошилова Н.В. Новая волна интереса к философской аргументации. Культура, человек и картина мира. Москва, 1987. С. 255. 
Today, such polyphony is mostly set by common theoretical and methodological interpretations of this concept. Among them, the most common are:

- information-semiotic

(Y.M Lotman,

H.-G. Gadamer, D.I. Dubrovsky, V.V. Ivanov, E. Cassirer, E. White, B.A. Uspensky, J. Shchepansky and others), according to which culture is understood as a system of "social codes", "signs" (they are the sounds of speech, letters, numbers, words and numbers, symbols, images, etc.), a certain number of texts (semantic information), expressed, coded In signs and symbols;

- activity (L.S. Vygotsky, N. Zlobin, L.N. Kogan, V.O. Lektorsky, O.M. Leontiev E.S. Markaryan, G.V. Sukhodolsky, etc.), whose representatives consider culture as a specific way of human activity, not only as a ready-made set of results of human life, but also a historically determined way of human attitude to the whole surrounding world, including himself. Cultural existence is seen as a person's activity in placing himself in the world around him - "objectification", "external activity", "alienation", as well as the reverse process of no less active "objectification", "assimilation and appropriation", internalization of products and results of previous activity ${ }^{19}$;

- synergetic (V.G. Budanov, S.P. Kapitsa, V.O. Kurinsky, S.P. Kurdyumov, G.G. Malinetsky, S.S. Khoruzhiy, etc.), determines the view of culture as independent, different from nature and society, the structure that arises through self-generation and creative selfdevelopment, self-organization of man, who becomes a person through culture;

- personal (R. Benedict, L.U. Kruglova, D. Markush, E.J. Rzhabek, L.V. Sokhan, M. Kherskovits, etc.), where culture is understood as a process of creative activity, essential human forces, creative selfrealization of the individual, which is considered as a subject of cultural and historical process, is both a means of forming and realizing the social forces of the individual, which operates in the cultural environment provided the assimilation of its achievements as a carrier and exponent of cultural values, creator of culture;

- axiological (A.K. Bychko, V.A. Blumkin, V. Windelband, N. Hartmann, O.B. Kravchenko, G. Rickert, M.S. Rozov, A.M. Feoktistov, etc.), according to which culture is defined as a system

19 Бистрицький С.К. Філософський образ культури та світ національного буття. Феномен української культури: методологічні засади осмислення. Київ : Фенікс, 1996. С. 68. 
of values created by humanity in the process of its development, the fundamental structure of social consciousness, which concentrates all the results of the spiritual activity of society, the system of life orientations;
- systemic
(V.P. Bespalko,
E.N. Gusinsky,
O.N. Zharikov, M.S. Kagan, V.M. Mezhuyev, M. Mead, T. Parsons, etc.), where culture is understood as a holistic unity of means and products of human activities in which its activity is realized and which contributes to its self-improvement, satisfaction and increase of needs, harmonization of relations between man and society, man and nature, society and nature ${ }^{20}$.

Since systemic thinking provides an opportunity to comprehensively illuminate the complex phenomenon of culture, and its existing interpretations should be considered as aspects, subsystems of understanding culture as a super-complex whole, in which material, spiritual, artistic, spiritual-material human actions that embody it are realized attitude to nature, society, ourselves, we prefer this approach.

Culture as a super-complex system is formed by the mutual transformation of three specific forms of its real existence, three modalities: human, in which culture is a set of acquired non-biological qualities by man and humanity; activity formed by a set of communitydeveloped methods of activity; objective, which covers all the "second nature", created and created by man. These include things, social institutions, works of various orientations and content, pedagogical acts and games. Because in cultural subjects a person "objectifies" his essential forces - needs, desires, ideals, thoughts and experiences - they can be isolated from these subjects and assimilated by each new generation and individual in acts of "objectification" of cultural information encoded in these subjects (knowledge, values, ideals, skills, technologies and so on $)^{21}$.

Thus, the main aspects of culture as a special sphere and form of activity, images of consciousness, which has its own structure and content, are characterized; as a set of social achievements, supernatural, man-made orders and objects that demarcate man and nature; as a specific system of values, norms, meanings, which are constructed by people to record and broadcast socially significant information, experience, technology, etc., characteristic of a certain level of development of society or its part; as a world of individuals, whose

20 Загвязинский В.И. Педагогическое творчество учителя. Москва : Педагогика, 1987. С. 138.

${ }^{21}$ Введение в культурологию. Курс лекций / под ред. Ю.Н. Солонина, Е.Г. Соколова. Санкт-Петербург, 2003. С. 7-8. 
consciousness and behavior are motivated and regulated not so much by biological as by social interests and needs, socially approved ways of their satisfaction and realization; as a spiritual dimension of activity in which its motives, principles, rules are formed; as a mechanism of social regulation and conditions of existence of society, support of its social consolidation.

\section{Cultural correspondence of higher and professional education}

Culture contains not only what exists outside man in the form of ideas, objects, values, technologies, etc., but also the changes he makes in himself and in man as a unity of physical and spiritual. It is the constant self-development, self-formation of the individual and humanity in general is a condition for considering culture not only as a tool for preserving a set of ready values, forms of human mentality, but also as a process of their transmission in specific cultural, historical and economic and social conditions. This is the reason for the idea of cultural conformity of education, put forward at one time by F. Disterweg.

The cultural correspondence of higher and professional education is conditioned by the understanding of education as an integral part and form of cultural transmission, as a culturally appropriate system and cultural process aimed at personal development. Education, according to P.A. Florensky, is a special environment that nourishes and cultivates the individual, a "tool" for the realization of its individual creative forces ${ }^{22}$.

The sequence of universal forms of preservation and transmission of the human possible expresses, on the one hand, the historical logic of culture in general and its main types, and on the other, the logic of human inclusion in culture, and hence the process of organizing cultural education. The logic of cultural forms is objectified into types of culture. Thus, the need to form a person capable of embodying the cultural experience multiplied by society, led to the emergence of special activities - pedagogical and a special kind of culture - pedagogical. After all, according to M.K. Mamardashvili, activity is culture to the extent that in its content is expressed and reproduced the very ability of man to have experience, the ability to reproduce it in time and space ${ }^{23}$.

A. Maslow deduces the cultural correspondence of education as a connection between culture and personality with the following thesis: on the one hand, personal consciousness, spiritual life of an individual is

\footnotetext{
22 Флоренский П.А. Разум и диалектика. Богословский вестник. 1914. № 9.

${ }^{23}$ Мамардашвили М.К. Наука и культура. Методологические проблемы историко-научных исследований. Москва : Наука, 1982. С. 42.
} 
determined by the world of culture as a set of absolute values, and on the other - the origins of culture lie in the depths of personal consciousness. culture, so the latter is the content of personality, which is expressed in the preservation and development of man as an organic component of $\operatorname{life}^{24}$. Human is understood here as an open, multidimensional, autonomous being, capable of self-development, in the same (capable of self-development) world. In addition, it means that a person is only one who has become the subject of action, activity, deed. Therefore, culture and the teacher do not create a person, but rather give the opportunity, create receptive conditions to become "real and relevant." Best of all, according to V.S. Bibler ${ }^{25}$, this possibility is manifested due to the dialogic nature of modern culture, which not only highlights and actualizes its various and multi-vector meanings, but also arises and forms a personality. The logic of dialogue creates a connection between the "Me" and the "Other" and reveals that the individual is derived from the external world, because the "Me" is called to respond to the "Other", but is declared in the world by its own statement. Creating the objectivity of social life in the process of professional or quasi-professional activity, the seeker of higher and professional education joins the socio-cultural diversity, gets the opportunity for self-development, through objectivity as the embodiment of human and professional values, norms, ideals, i.e. meanings of life. and the material content of culture.

Applicants for higher and professional education not only develop on the basis of the development of culture, but also replenish it with new elements, ensure its improvement and development. Culture acts as a historical process of creating new, perfect meanings and meanings. Therefore, the assimilation of cultural values is the development of man himself, his formation as a person and a competitive professional. In addition, a person of culture is understood as a carrier of general and individual culture in their unity and harmony; a well-rounded personality who has mastered the national and general cultural experience of previous generations and lives by humanistic principles; type of personality, the core of which are the features that determine the degree of its freedom, humanity, spirituality, creativity ${ }^{26}$.

${ }^{24}$ Маслоу А.Г. Дальние пределы человеческой психик / пер. с англ. А.М. Талдыдаевой. Санкт-Петербург : Изд. группа «Евразия», 1997. 430 с.

${ }^{25}$ Библер В.С. Мышление как творчество. Москва : Политиздат, 1975. 399 с.

26 Меняйлова Т.А. Формирование качеств личности человека культуры у школьников на основе реализации культурологического похода: автореф. дис. ... канд. пед. наук : 13.00.01. Новокузнецк, 2008. С. 7. 
Education and culture, in the metaphorical words of V.F. Sidorenko, form a "big breath", during which rhythmically there is a "breath" and "exhalation". During the "breath" education "draws" the whole culture, which is its content and subject for creative reproduction. At this moment, education becomes a special form and image of culture. When there are "exhalations", culture is reproduced in man, giving society a cultural form and capacity ${ }^{27}$.

The architectonics of higher and professional education, which is part of culture, its structure, form, mode of action, should be similar to the logic of culture. In order for this "breathing" to happen, culture must enter education, defining not only its structure, but also the logic of the teacher's actions, the strategy of their organization. Precisely because the culture of industrial society, focused on obtaining ready knowledge and information, is gradually replaced by modern, post-industrial, aimed at the birth of living thought, creative value-oriented activity of a particular future specialist, "man of culture", able not only to acquire knowledge but and work with them, comprehend, appropriate the ideas of different cultures for self-realization in life, associated with the change of educational paradigms.

The humanistic culturally appropriate paradigm of education returns it to the essential characteristics of man, to the need to form thought, understanding, not just knowledge, because it arises in a situation of ignorance, overcome only by human activity, asserts its self-worth as a unique personality, the only source of productive action ${ }^{28}$.

The task of higher and professional education in general and the teacher in particular, is to create a cultural situation that promotes the emergence of learners, and knowledge-information (as sustainable cultural values, scientific achievements...), and knowledge-thoughts (as personal meanings that are born only due to one's own effort, activity of the individual and is an act of personalized creativity, individual (or absolute) discovery). They lead to the construction of their own, albeit one that mostly coincides with the already existing, cultural world.

A special system of worldview and universe introduces a new method of higher and professional education, which is to know the phenomena not as those that are subject to separate consideration, but as studied from

27 Сидоренко В.Ф. Образование: образ культуры. Социально-философские проблемы образования. Москва, 1992. С. 34-52.

28 Кремень В.Г. Інноваційна людина в стратегіях освіти. Професійна освіта: педагогіка і психологія : польсько-український щорічник. Ченстохова - Київ, 2008. Вип. Х. С. 37-49. 
the standpoint of their value and meaning in the overall chain of events. This method provides a scientific basis for not only the possibility but also the need to use interdisciplinary links in higher and vocational education $^{29}$.

Thus, the culturally appropriate educational paradigm reflects the direction of the education system on the activation of personal principles of learning, self-creation through knowledge, needs human individuality, which most fully reflects the organic coexistence of man and culture, the desire to preserve and create, involves the transition to new organizational -methodical principles of teaching.

\section{Principles of culturally appropriate higher and professional education}

Principles in education, including higher and professional, are the basis for the implementation of a particular educational paradigm, they set a system of requirements and rules, indicate how to act in the best way to justify a pedagogical innovation and regulate its application ${ }^{30}$.

According to V.V. Kraevsky, the principle, as a phenomenon of methodological knowledge, expresses the orientation of any type of professional activity on the transformation of practice, where "along with the existing characteristics of the object industry, also reflects trends, opportunities for change and transformation" 31 .

Note that the objective criterion that led to the selection of the principles of culturally relevant higher and professional education was their importance in the implementation of this process.

The implementation of culturally appropriate higher and professional education involves, on the one hand, mastering the "sustainable" culture of society, and on the other hand, requires not only cultural development, cultural reproduction, but also cultural creation, as the development of subjectively and objectively new cultural artefacts (material and spiritual). Comparison and coexistence of "sustainable", new and generated, fully implements the principle of additionality. For the first time, the principle of additionality, as a new "logical tool" that allows in the process of cognition to reproduce the integrity of its object, analysis

29 Княжева І.А. Теоретико-методологічні засади розвитку методичної культури майбутніх викладачів педагогічних дисциплін в умовах магістратури : монографія. Одеса : ФОП Бондаренко М.О., 2014. 328 с.

${ }^{30}$ Гончаренко С.У. Український педагогічний словник. Київ : Либідь, 1997. C. 270 .

31 Краевский В.В. Методология педагогики : пособие для педагоговисследователей. Чебоксары : Изд-во Чуваш. ун-та, 2001. С. 9. 
of its inherent contradictory properties, apply additional mutually exclusive classes of concepts in the form of "additional pairs", to establish equivalence between them. With the need to interpret quantum mechanics $\mathrm{N}$. Bor ${ }^{32}$. Unlike the classical formal-logical rules of connection of mutually exclusive statements, this principle substantiates the equivalence of two additional descriptions.

The principle of additionality is most often formulated as follows: in the system of properties of any object and subject always relatively stable and asymmetrically harmonize pairs of complementary and in particular opposite properties, qualities, features and forms, simultaneous and equally bright manifestation of which is impossible or unlikely ${ }^{33}$.

Peculiarities of the manifestation of additionality in other spheres of human existence are described in the scientific works of I.S. Alekseev, A.D. Armand, G.G. Granatov, J. Derrida, U.M. Lotman, and others. The authors note that the dialogue of natural and humanitarian cultures is explained by the natural additionality of culturally appropriate and nature-appropriate bases in human thinking, consciousness and behavior. It is proved that additionality presupposes not an ordinary complement, but a certain asymmetric harmony, the unity of the opposing, the pluralism of relative truths that make up a holistic picture of reality.

According to I.S. Alekseev ${ }^{34}$, the concept of additionality can be used as a methodological principle to solve conceptual difficulties that arise in non-physical fields of knowledge, because the results of human activity in any field must inevitably be described by means of ordinary language. At the same time, the principle of additionality regulates the "nonclassical" use of "classical" concepts. M.O. Rozov emphasizes the possibility of wide application of this principle in the humanities to a large number of problems, revealing their internal unity and allowing to understand the difficulties that are usually associated with their discussion, pointing out that "practical application of the theory is in additional attitude to attempts to formulate it precisely". It is emphasized that this principle manifests itself in the humanities also by the fact that the activities of people in them are organized not only on an abstract level.

32 Бор Н. Причинность и дополнительность. Избранные научные труды. Москва, 1971. Т. 2. 278 с.

33 Гранатов Г.Г. Концепция дополнительности в философии образования человека (диалектика и психология мышления). Магнитогорск : МаГУ, 2008. $230 \mathrm{c}$.

${ }^{34}$ Алексеев И.С. Концепция дополнительности: историкометодологический анализ. Москва : Наука, 1978. 276 с. 
Understanding of additionality as a general scientific and philosophical principle, carried out in the scientific works of L.B. Bazhenov, V.G. Mushich-Gromyko, M.O. Rozov, B.C. Stepin, I.T. Frolov, etc., is associated with the leading elements traditional philosophy, centered on the problem of stability and variability, unity and plurality, on the unchanging in changing phenomena, on the importance of the expression of being in the logic of concepts, and so on. The essence of the principle of additionality is determined in them through the finding of constant (general; invariant) in different, contradictory representations, as a system of rational epistemological principles, through which it is possible to adequately explain these phenomena. It is emphasized that being, which has disintegrated as a result of research procedures into two components (classical and nonclassical knowledge) through appropriate representations, is reassembled, synthesized through theoretical thinking, becoming an adequate picture of phenomena and processes ${ }^{35}$. A kind of bridge is created between classical and non-classical methods of cognition, which helps to relieve tension between semantic antinomies, and hence the tension in the epistemological procedures of cognition, and then - in the immediate life of man.

In philosophical and psychological-pedagogical researches of various aspects of cognition, thinking (E. de Bono, G.G. Granatov, O.S. Kaminsky, N.O. Plugina, etc.) the method of additionality as the dialectical method of cognition which initial position is allocated there is a combination in the human mind of consciously verbalized, unconscious and emotional spheres of the psyche. The development of this idea leads to assumptions about the merging of dialectics, styles of thinking and worldview. Thus, E. de Bono concludes that the irrational (dominated by intuition, creativity) and rational (vertical, which is characterized by selectivity, constancy) types of thinking come to the conclusion ${ }^{36}$.

G.G. Granatov's research solves the problems of dialectical presentation of the properties and forms of pedagogical thinking, the development of scientific concepts with the help of additionality, which is interpreted as a relatively stable asymmetric (with a possible rhythmic change of the dominant) harmony or unity of opposing and in particular

${ }^{35}$ Мушич-Громыко В.Г. Методологические возможности принципа дополнительности в формализованных и неформализованных знаниях через опору на понятие пространство : монография. Новосибирск : Ред.-изд. центр НГУ, 2010. 207 c.

36 Гурова Л.Л. Принятие решений как проблема психологии познания. Вопросы психологии. 1984. № 1. С. 125-132. 
really opposite principles or regularities ${ }^{37}$. In particular, it is proved that the awareness of additionality, naturalness and cultural conformity of human thinking is the main basis for the choice and construction of its process model. The psychological and pedagogical principle of additionality is determined: in the thinking and character of any person pairs of complementary or opposite properties, forms or qualities, the simultaneous and equally bright manifestation of which is impossible or unlikely, harmonize relatively stable.

Based on this principle, an appropriate method was developed as a form of knowledge based on representations of object models (in this case, models of the concept of "dialectical pedagogical thinking") and a sequence or pattern of actions that combine a common idea and lead to a specific goal or spectrum tasks. Its technological part contains eleven elements of the reflexive-additional approach used to achieve the highest possible level of development of such thinking and the appropriate level of mastery of the method of additionality.

The properties and regularities of dialectical thinking manifest themselves externally through complexes of such usually opposed principles of transformative influence: learning at high and accessible levels of difficulty, at an accelerated and natural pace; priority of theory and clarity (as the addition of methods of induction and deduction), etc. The principle of additionality orients the teacher and the applicant of higher and professional education on studying of the phenomena, subjects and processes from different parties, comprehending their rational-logical and emotionally-figurative maintenance; the ability to perceive a problem as multifaceted, to simultaneously see, take into account or combine several opposite conditions, preconditions and principles.

Reflecting on the manifestation of additionality in the humanities, M.O. Rozov emphasizes the comparison and coexistence of theory and practice, on the border of which, if we concretize this idea of pedagogical theory and pedagogical practice, as shown in the second section, there is a methodological culture as a sociocultural phenomenon. Its occurrence is closely connected with the appearance of patterns, standards of activity. Their assignment can take place as a personal deployment of the described, recorded in the texts of the samples and, taking the logic of reasoning M.O. Rozov, as a "social relay", although only if you understand the context of the activity (and changing the context can

${ }^{37}$ Гранатов Г.Г. Метод дополнительности в развитии понятий (педагогика и психология мышления) : монография. Магнитогорск : МаГУ, 2000. 195 с. 
change the content of samples) as its direct participant. Such participation may consist in the practical reproduction of the actions of the sample or in an attempt to describe them, to enshrine them in the texts. Here it is necessary to add two descriptions: the activity within which the "relay" is carried out is fixed, or the mechanism of activity (rules, algorithms) as its reflexive reflection. The first strategy allows you to capture more and more new samples and reproduce them directly, and the second - to absolute these descriptions, creating rules (methodological products), which should continue to be carried out. Both of these strategies (real actions and their reflective reflections) coexist on the principle of additionality. Thus, the introduction of the content of professional and pedagogical training of future teachers of pedagogical disciplines for the development of their methodological culture, the principle of additionality will help to understand the essence of its genesis and development.

In higher and vocational education, the principle of additionality also manifests itself in the interdependence, coexistence and interaction of classical and innovative features of the educational process. Their comparison is natural and necessary, and the opposition often prevents us from discovering how they interact with each other, complement and develop each other. Additionality allows to add, to "complete", to supplement the best developments of sustainable methodological culture with new, modern ones. After all, to successfully solve educational problems, achieve a synergistic effect, we must not forget and contrast one method, tool, technology with another, and naturally and expediently use their capabilities, organically weaving into the outline of the educational process of higher and vocational school ${ }^{38}$.

The principle of electivity (from the Latin "electus" - selected, selective) is recognized as a core in adult learnings features are the need for meaning (justification), independence, taking into account life experience as a system of skills, ways of action ("practical knowledge"), awareness of the urgent need, practical orientation. This principle allows us to implement the basic andragogical idea that an adult who clearly understands the purpose of learning, seeks independence, selfrealization, has a leading role in the process of obtaining their own education, professional development and self-development.

38 Княжева I.А. Реалізація принципу додатковості в розвитку методичної культури майбутніх викладачів педагогічних дисциплін спеціальності «Дошкільна освіта». Збірник наукових доповідей «Актуальні проблеми сучасної дошкільної та вищоӧ освіти». Лодзь, 2014. С. 58-59. 
The principle of electiveness states that every future specialist enjoys a certain freedom in the organization of their activities aimed at preparing him for future professional activities. This principle provides for the right to choose independently from several alternatives, a certain freedom for pupils and students as subjects of education in choosing the goals, content, forms, methods and sources of learning, its intensity (as their own pace and rhythm of progress in mastering the content of training) depending on their interests and needs.

The implementation of this principle, according to the research of Z.V. Vozgova, S.I. Zmeev, V.I. Podobeda requires: knowledge of the individual characteristics of those who receive education, their personal and educational achievements; realization of the right of future specialists to their own vision of the situation, reliance on their current interests; implementation of diagnostic, facilitating, supporting activities of the teacher as a tutor; application of a wide range of forms and methods of building the educational process in higher and vocational school; encouraging students to self-knowledge and self-esteem based on the formation of skills to act consciously in situations of cultural choice $^{39}$.

The principle of dialogicity is based on a dialogical approach, according to which dialogue is a universal and absolute characteristic of human existence in various spheres of reality, immanent essence, phenomenological characteristic of culture, way of realization of its functions as culture not only forms and defines essential characteristics of the person, but also realizes them in dialogue, in the exchange of information, concepts, knowledge. Any manifestation of man is seen here as a cue in this great, global dialogue.

The dialogic nature of being, culture, science, thinking is reflected in the polyphony of science, culture and personal consciousness of modern man as a dialogue of different voices, positions, values, meanings. Dialogue is a pledge and condition of human existence, a way of knowing reality and oneself, as it is an objectification of personal knowledge, is a basic condition of consciousness, selfconsciousness and dialectical-communicative environment that provides subject-semantic communication, reflection of selfrealization ${ }^{40}$.

39 Змеев С.И. Технология обучения взрослых : учебное пособие. Москва : Издательский центр «Академия», 2002. 128 с.

40 Розин В.М., Булдаков С.К. Философия образования : учебное пособие. Кострома : Изд-во КГУ им. Н.А. Некрасова, 1999. 284 с. 
M.M. Bakhtin considered dialogue a universal concept that "permeates everything: human speech and all relationships, all manifestations of human life in general, everything that has meaning and significance" 41 , considered it as a process of interaction of different contexts, dissimilar thoughts, different expressive- accent systems, various personal entities, emphasized that dialogue is a process in which the individual characterizes himself and, thus, able to "realize" himself in the true sense, because only in communication, in the relationship between man and man reveals "man in man", both for others and for himself.

G.V. Dyakonov in his interpretation of the dialogue, which summarizes its various interpretations, notes that "the true essence and content of the dialogue is that this phenomenon is generated, manifested and realized in the following basic guises (dimensions): as a process, event, coexistence, identity, otherness" ${ }^{\text {42 }}$.

Dialogue is seen as a general principle of optimal organization and management, a way of learning, where its subject is involved in the process of cognition and interaction with the outside world; form and means of subject-subject pedagogical interaction, "interaction that lasts indefinitely" "This implies the attitude to each significant and responsible participant as a unique individual, whose thoughts, aspirations and views are valuable and important. The position of the interlocutor transforms the teacher from a source of information and a controlling authority into an organizer and participant in the pedagogical process, which encourages the birth in the process of free exchange of ideas of new knowledge as a personal finding of meanings and values of the future profession.

In terms of higher and professional education, the dialogue of the individual is able to form a common psychological space, a single emotional "coexistence" ("co-existence"), in which influence (in the usual, objective, monologue essence of this concept) ceases to exist, giving way to psychological unity of subjects of education, in which the creative process of mutual disclosure and mutual development unfolds, conditions for self-influence and self-development are created. C. 49 .

41 Бахтин М.М. Эстетика словесного творчества. Москва : Искусство, 1979.

42 Дьяконов Г.В. Основы диалогического подхода к психологической науке и практике : монография. Кировоград : РИО КГПУ им. В. Винниченка, 2007. C. 8-9.

43 Гржегорчик А. Духовная коммуникация в свете идеала ненасилия. Вопросы философии. 1992. № 3. С. 56. 
Being adequate to the subject-subject character of human nature itself, dialogue is "the most relevant for the organization of the most productive and personally developing contacts between people", points out G.O. Kovalev ${ }^{44}$.

The principle of dialogicity provides:

- dialogical attitude to the world, to himself, to another person;

- internalization of externally set educational tasks in internally determined personal meanings;

- focus not on information, not on the assimilation of ready-made knowledge, but on problems, the search for truth, personal meaning;

- providing the content of communication openness, ambiguity, nonlinearity;

- dialogical position of the teacher and the student in the educational process;

- openness of target instructions of the teacher and improvisation of his activity;

- the use of forms and methods of teaching adequate to the essential nature of dialogue (discussion, debate, problem lecture, Internet dialogue, etc.).

The principle of context helps to overcome the contradictions between the construction of educational material according to the logical structure of scientific knowledge (it is presented within traditional education in such a general way that the actions, context and results of the proposed theoretical model are not clear to those who receive education) and the need for future professionals. In new knowledge and skills that are not generalized (abstract) but situational (practice-oriented), included in the context of future professional activity.

This principle outlines the way to overcome this contradiction by analysing the real needs of participants in the educational process, thematic linking of theory (theoretical knowledge) to typical situations of professional reality to acquire practical knowledge as a set of cultural skills, abilities, methods of action, customs, standards. Theoretical knowledge is acquired in the context of practical action, and practical knowledge is based on the appropriate theoretical basis. Moreover, the requirements of professional activity are systemforming, they set the contextual principle of construction and deployment not only of individual disciplines, but also the entire

44 Ковалев Г.А. Общение и диалог в практике обучения, воспитания и психологической консультации. Москва : Просвещение, 1987. С. 51. 
training of future professionals, during which he is put in an active position, and the subject becomes practice-oriented. This is due to the design of academic disciplines not only as sign systems and activities for their development, but is carried out in the context of professional activities. Under these conditions, theoretical knowledge begins to perform the functions of an indicative basis of activity, and forms of organization of learning - the functions of reflecting its content ${ }^{45}$.

According to A.A. Verbytsky, the reproduction of the subject and social contexts of professional activity "adds" to the educational process a number of new aspects, among them: the space-time context "past - present - future'. Then the educator knows what to expect and can interpret it meaningfully. Before acting, thanks to the availability of contextual information, the learner is oriented in today's professional field and gets the opportunity to model how professional activities should unfold in the future. Systematic and interdisciplinary knowledge, the possibility of dynamic deployment of learning content, which is usually given in statics, role "instrumentation' of professional actions and deeds are inherent in learning within the principle of context ${ }^{46}$.

Implementation of the principle of contextuality involves modelling with the help of the whole system of didactic forms, methods and technologies of subject and social content of future professional activity, ensuring its cultural nature.

Before characterizing the principle of subjectivity, let us define our own understanding of subjectivity. In philosophy, its interpretation is connected with the Cartesian tradition of understanding human consciousness, embodied in the "I who thinks", which is now understood as a source of spontaneous social and cognitive activity, a sovereign figure. A subject is a person who possesses the attributes of rationality, integrity and sovereignty, free, one who chooses the goals of his activity. Subjectivity determines the specifics of human existence, the activity of the individual, serves to describe his place in the world.

There are certain stages of subjectogenesis that a person has to go through constantly. The first, the manifestation of oneself as the subject of future action, is manifested in the person's acceptance of

45 Вербицкий А.А. Активное обучение в высшей школе: контекстный подход : методическое пособие. Москва : Высшая школа, 1991. 207 с.

46 Вербицкий А.А. Компетентностный подход и теория контекстного обучения. Москва : ИЦ ПКПС. 2004. С. 46. 
responsibility for the possible outcome of his actions. The second stage - the manifestation of himself as a subject of goal-setting - is manifested in the experience of the possibility of realizing different options for the future, his involvement in building the image of the desired result and the ability to realize the desired. The third is the manifestation of oneself as a subject of actions that take place "here and now", as the realization of the possibilities that are in the actions carried out of one's own free will. The next stage is marked by the manifestation of oneself as the subject of the action that took place, and the evaluation of the result as a personally significant neoplasm, determined by one's own activity.

V.A. Petrovsky ${ }^{47}$ that the desire to "be a person" due to the idea of subjectivity can be expressed, first, in the desire (activity) of man to be the subject of their vital contacts with the world; secondly, in an effort to be a subject of substantive activity. This is manifested through value-semantic formations, mechanisms of self-regulation. Third, it is the desire to be a subject of communication, which recognizes the "otherness" of another, which is characterized by openness and willingness to renew (discourse); fourth, to be the subject of selfconsciousness, that is, the process of generating the image of one's "I".

The subjectivity of the individual is manifested in the fact that it produces, creates fundamentally new opportunities, rationally reasonable forms, generates what for nature lies beyond the limits of what is possible. But man-made activity becomes a new part of nature, a cultural heritage. Subjectivity in a person is opposed to the elimination of the personal principle, impersonality, lack of selfcriticism and reality, independence and self-activity, the ability only to perform functions.

We share the opinion of L.A. Nedoseki ${ }^{48}$, according to which subjectivity is a qualitative and dynamic characteristic of a person integrated into modern socio-cultural realities of intercultural dialogue, which testifies to the ability to act in conditions of freedom, meaningmaking and meaning-making, to take an active position. in their activities, proactively and creatively create ways and conditions for solving professional tasks, reflect and predict the results of activities.

47 Петровский В.А. Личность в психологии: парадигма субъектности. Ростов-на-Дону : Феникс 1996. 512 с.

48 Недосека Л.А. Развитие субъектности студентов в процессе обучения языку : автореф. дис. ... канд. пед. наук : 13.00.08. Ростов-на-Дону, 2005. 20 с. 
Manifestation of subjectivity in educational activities can occur, for example, in spontaneous generalization and non-pragmatic formulation of the problem, self-determination of the level of complexity of the task, the desire to go beyond certain, given by a particular situation, the framework of socio-role interaction. is reduced to mobilization, agreement with the requirements of reality, communication with the activity of other people. The formation of subjectivity in this regard involves overcoming a certain information uncertainty in the management of human activity from the beginning of goal setting to the final evaluation of the results achieved. Thus, conscious active activity is the most important indicator of subjectivity, as it indicates the ability of an individual to realize his rational goals and ideals ${ }^{49}$. Thus, this principle allows us to consider the future specialist as a subject of activity, self-improvement, self-realization, self-reflection and self-regulation of their own activities, which are manifested at all stages of training.

It should be noted that all the principles are interconnected and interdependent and constitute a certain system that ensures the implementation of a culturally appropriate paradigm of higher and professional education.

\section{CONCLUSIONS}

The relevance and feasibility of studying the problem of ensuring cultural relevance of modern domestic higher and vocational education is due to the need to resolve contradictions between: the social order for the modernization of higher and vocational education and the need for scientifically sound, proven models of its cultural development; the need for professional training of future qualified specialists capable of understanding, processing and appropriation of basic meanings and forms of professional activity and the need for theoretical and methodological support of such culturally appropriate training.

A retrospective analysis of the definition of "culture" allowed to give preference to the existing in scientific discourse systemic definitions of culture, considering it in dynamics, because it is not only a certain achievement of mankind, but also the sum of social achievements in constant development. Culture is not only a given of ready-made results of human activity, but also a historically concrete,

49 Княжева И.А. Реализация технологии развития методической культуры будущих преподавателей педагогических дисциплин. Концепт. 2014. № 3. URL: http://e-kon-cept.ru/2014/14065.htm. 
definite way of human attitude to nature, society, oneself, in the process of which people assimilate previously created culture and produce new ones on the basis of acquired knowledge, skills, abilities. values, objectify the subjectively assimilated and appropriated. Culture is a universe of general, social or generic forms and norms of life, which have been developed in the course of history as significant.

A culturally appropriate educational paradigm ensures the return of the theory and practice of education to the context of culture, rethinking the strategic goal of higher and professional education - the formation of the personality of a highly qualified specialist as a person of culture. The analysis of the scientific fund allowed to single out, substantiate and describe the system of basic principles of culturally appropriate higher and professional education (additionality, dialogicity, contextuality, subjectivity, electiveness).

\section{SUMMARY}

The relevance of the implementation of high-quality culturally relevant higher and professional education is proved in the work. The scientific analysis of the genesis and development of the definition of "culture" in scientific discourse is carried out, the most common modern approaches (information-semiotic, activity, synergetic, personal, axiological, systemic) to its definition are characterized. The scientific power and perspective of systemic thinking are motivated, which provides an opportunity to comprehensively cover the complex phenomenon of culture, and its existing interpretations to consider as aspects, subsystems of understanding culture as a superstructural integrity in which material, spiritual, artistic, spiritual and material human actions are realized, embodying her attitude to nature, society and herself. It is shown that the cultural correspondence of higher and professional education is conditioned by the need to return the theory and practice of education to the context of culture, rethinking the strategic goal of higher and professional education - the formation of a highly qualified specialist as a person of culture. The basic principles of culturally appropriate higher and professional education are scientifically substantiated, their features and prospects of their development in the educational process are revealed and characterized.

\section{References}

1. Про професійну (професійно-технічну) освіту. Проєкт закону України від 12 жовтня 2020 р. № 4207. URL: http://search.ligazakon.ua/1_doc2.nsf/link1/JI03403A.html. 
2. Закон України «Про освіту»: Закон України від 05 вересня 2017 p. № 2145-VIII. URL: https://zakon.rada.gov.ua/laws/show/214519\#Text.

3. Цицерон М.Т. Сборник статей / отв. ред. Ф.А. Петровский. Москва : Изд-во АН СССР, 1958. $151 \mathrm{c.}$

4. Кулиев Г.Г., Курбанов Р.О., Драч Г.В. и др. Зарубежное философское антиковедение: Критич. анализ / отв. ред. Д.В. Джохадзе; АН СССР, Ин-т философии. Москва : Наука, 1990. $236 \mathrm{c}$.

5. Гоббс Т. Левіафан, або Суть, будова і повноваження держави церковної та цивільної. Київ : Дух і Літера, 2000. 600 с.

6. Бекон Ф. Зарубіжні письменники. Енциклопедичний довідник : у 2 т. / за ред. Н. Михальської та Б. Щавурського. Тернопіль : Навчальна книга - Богдан, 2005. Т. 1. С. 116.

7. Нидерман И. Культура, становление и изменение понятия и заменяющие его понятия от Цицерона до Гердера. Москва : Просвещение, 1992. 422 с.

8. Французский материализм XVIII века. Учение об обществе. Хрестоматия. Москва : Либроком, 2011. 264 с.

9. Strohbach M. Johann Christoph Adelung. Ein Beitrag zu seinem germanistischen Schaffen mit einer Bibliographie seines Gesamtwerkes. Berlin; New York: Walter de Gruyter, 1984. (Studia Linguistica Germanica; 21).

10.Гердер И.Г. Идеи к философии истории человечества. Москва : Издательство «Наука», 1977. 705 с.

11.Кант И. Критика чистого разума. Москва : Издательство «Наука», 1999. 655 с.

12.Гегель Г.Ф.В. Философия права. Москва : Мысль, 1990. 524 с.

13. Тайлор Э.Б. Первобытная культура / пер. с англ. Москва : Политиздат, 1989. 573 с.

14.Культурологія: теорія та історія культури : навчальний посібник / за ред. І.І. Тюрменко. Київ : Центр навчальної літератури, $2010.370 \mathrm{c}$.

15. Kroeber A.L., Kluckhon C. Culture. A Cretical Review of Concept and Definitions. Harvard Univ., 1952. P. 10-29.

16. Kaplan D., Manners R.A. Culture Theory. New York, 1972.

17.Философский словар / под ред. М.М. Розенталя. Москва : Политиздат, 1975. $496 \mathrm{c}$.

18. Мотрошилова Н.В. Новая волна интереса к философской аргументации. Культура, человек $и$ картина мира. Москва : Издательство «Наука», 1987. С. 255-258. 
19.Бистрицький Є.К. Філософський образ культури та світ національного буття. Феномен української культури: методологічні засади осмислення. Київ : Фенікс, 1996. С. 62-90.

20.Загвязинский В.И. Педагогическое творчество учителя. Москва : Педагогика, 1987. 160 с.

21.Введение в культурологию. Курс лекций / под ред. Ю.Н. Солонина, Е.Г. Соколова. Санкт-Петербург, 2003. 167 с.

22. Флоренский П.А. Разум и діалектика. Богословский вестник. 1914. № 9. С. 36.

23. Мамардашвили М.К. Наука и культура. Методологические проблемы историко-научных исследований. Москва: Наука, 1982. $360 \mathrm{c}$.

24. Маслоу А.Г. Дальние пределы человеческой психики / пер. с англ. А.М. Талдыдаевой. Санкт-Петербург : Изд. группа «Евразия», 1997. $430 \mathrm{c}$

25.Библер В.С. Мышление как творчество. Москва : Политиздат, 1975. 399 с.

26.Меняйлова Т.А. Формирование качеств личности человека культуры у школьников на основе реализации культурологического похода : автореф. дис. ... канд. пед. наук : 13.00.01. Новокузнецк, 2008. $27 \mathrm{c}$.

27.Сидоренко В.Ф. Образование: образ культуры. Социальнофилософские проблемы образования. Москва, 1992. С. 34-52.

28.Кремень В.Г. Інноваційна людина в стратегіях освіти. Професійна освіта: педагогіка $і$ психологія : польсько-український щорічник. Ченстохова - Київ, 2008. Вип. Х. С. 37-49.

29.Княжева I.A. Теоретико-методологічні засади розвитку методичної культури майбутніх викладачів педагогічних дисциплін в умовах магістратури : монографія. Одеса : ФОП Бондаренко М.О., 2014. $328 \mathrm{c}$.

30.Гончаренко С.У. Український педагогічний словник. Київ : Либідь, 1997.376 с.

31.Краевский В.В. Методология педагогики : пособие для педагогов-исследователей. Чебоксары : Изд-во Чуваш. ун-та, 2001. $244 \mathrm{c}$.

32.Бор Н. Причинность и дополнительность. Избранные научные трудыл. Москва, 1971. Т. 2. 278 с.

33.Гранатов Г.Г. Концепция дополнительности в философии образования человека (диалектика и психология мышления). Магнитогорск : МаГУ, 2008. 230 с. 
34. Алексеев И.С. Концепция дополнительности: историкометодологический анализ. Москва : Наука, 1978. 276 с.

35.Розов М.А. Явление дополнительности в гуманитарных науках. Теория познания : в 4 т. Т. 4 . Познание социальной реальности. Москва, 1995. С. 208-227.

36. Мушич-Громыко В.Г. Методологические возможности принципа дополнительности в формализованных и неформализованных знаниях через опору на понятие пространство : монография. Новосибирск : Ред.-изд. центр НГУ, 2010. 207 с.

37.Гурова Л.Л. Принятие решений как проблема психологии познания. Вопросы психологии. 1984. № 1. С. 125-132.

38.Гранатов Г.Г. Метод дополнительности в развитии понятий (педагогика и психология мышления) : монография. Магнитогорск : МаГУ, 2000. 195 с.

39.Княжева I.А. Реалізація принципу додатковості в розвитку методичної культури майбутніх викладачів педагогічних дисциплін спеціальності «Дошкільна освіта». Збірник наукових доповідей «Актуальні проблеми сучасної дошкільної та вищої освіти». Лодзь, 2014. C. 58-59.

40.Змеев С.И. Технология обучения взрослых : учебное пособие. Москва : Издательский центр «Академия», 2002. 128 с.

41.Розин В.М., Булдаков С.К. Философия образования : учебное пособие. Кострома : Изд-во КГУ им. Н.А. Некрасова, 1999. 284 с.

42.Бахтин М.М. Эстетика словесного творчества. Москва : Искусство, 1979. 424 с.

43.Дьяконов Г.В. Основы диалогического подхода к психологической науке и практике : монография. Кировоград : РИО КГПУ им. В. Винниченка, 2007. 847 с.

44.Гржегорчик А. Духовная коммуникация в свете идеала ненасилия. Вопросы философии. 1992. № 3. С. 54-64.

45.Ковалев Г.А. Общение и диалог в практике обучения, воспитания и психологической консультации. Москва : Просвещение, 1987. 87 с.

46.Вербицкий А.А. Активное обучение в высшей школе: контекстный подход : методическое пособие. Москва: Высшая школа, 1991. $207 \mathrm{c.}$

47.Вербицкий А.А. Компетентностный подход и теория контекстного обучения. Москва : ИЦ ПКПС. 2004. 84 с.

48.Петровский В.А. Личность в психологии: парадигма субъектности. Ростов-на-Дону : Феникс 1996. 512 с. 
49.Недосека Л.А. Развитие субъектности студентов в процессе обучения языку : автореф. дис. ... канд. пед. наук : 13.00.08. Ростовна-Дону, 2005. 20 с.

50.Княжева И.А. Реализация технологии развития методической культуры будущих преподавателей педагогических дисциплин. Кониепт. 2014. № 3. URL: http://e-kon-cept.ru/2014/14065.htm.

Information about the author: Knyazheva Iryna Anatoliivna, Doctor of Pedagogical Sciences, Professor, Head of the Department of Pedagogy, State Institution "South Ukrainian National Pedagogical University named after K. D. Ushynsky", 26, Staroportofrankivska str., 65020, Odessa, Ukraine 